\title{
Tinjauan Konseptual Berita Bohong pada Pengelolaan Platform Komunikasi Hoax Buster https://covid19.go.id/p/hoax-buster
}

\author{
Andhika Febi Hardina ${ }^{1}$, Irwansyah ${ }^{2}$ \\ ${ }^{1}$ (Department of Communication Science, Universitas Indonesia) 2006503664, andhika.febi@ui.ac.id \\ ${ }^{2}$ (Department of Communication Science, Universitas Indonesia), dr.irwansyah.ma@gmail.com
}

\begin{abstract}
ABSTRAK
Penelitian ini membahas mengenai kolom Hoax Buster pada covid19.go.id yang menjadi platform pemerintah dalam menyampaikan informasi terkait Covid-19 kepada masyarakat. Penelitian ini dilatar belakangi dimana banyak misinformasi yang beredar pada berbagai platform media sosial selama pandemi Covid-19 terjadi. Penelitian ini menggunakan metode kualitatif dengan analisis konseptual dalam meninjau berbagai sumber dari penelitian terdahulu. Hasil dari penelitian ini menunjukkan bahwa gangguan informasi terjadi karena adanya kepanikan masal dan kurangnya kesadaran, serta sedikit wawasan mengenai Covid-19. Dengan hadirnya Hoax Buster pada situs resmi pemerintah, diharapkan masyarakat dapat meningkatkan kemampuan dalam memfilter berita-berita hoaks mengenai Covid-19 sehingga mampu menekan angka Covid-19.
\end{abstract}

\section{Kata Kunci: Hoax Buster, Media Sosial, Berita Pandemi Covid-19, Gangguan Informasi}

\section{ABSTRACT}

This study discusses the Hoax Buster column at covid19.go.id which is the government's platform in conveying information related to Covid-19 to the public. This research was motivated by a lot of misinformation circulating on various social media platforms during the Covid-19 pandemic. This study uses qualitative methods with conceptual analysis in reviewing various sources from previous research. The results of this study indicate that information disorder occurs because of mass panic and lack of awareness, as well as little insight into Covid19. With the presence of Hoax Buster on the government's official website, the public can improve their ability to filter hoax news about Covid-19 so that they can reduce the number of Covid-19.

Keywords: Hoax Buster, Social Media, Covid-19 Pandemic News, Information Disorder

\section{Pendahuluan}

Sudah setahun lebih dunia dilanda wabah besar semenjak World Health Organization (WHO) mengidentifikasi info pandemic besar yaitu virus Corona (COVID 19) pada 11 Maret tahun 2020 banyak beredar informasi mengenai Covid-19 yang belum teruji kebenarannya. Covid-19 yang semakin lama semakin meningkat sejalan dengan infodemik yang kian menyebar luas. Hal ini menyebabkan informasi yang berlebihan terkait Covid-19 ini, sehingga banyak masyarakat merasa bingung untuk mengidentifikasi sumber berita mengenai virus ini. Akibat daripada penyebaran informasi ini menciptakan kepanikan masyarakat dan menghilangkan rasa ketidak percayaan terhadap tenaga 
kesehatan maupun pihak pemerintah. Meningkatkanya informasi yang berlebihan seputar Covid-19, misalnya seperti lewat tatap muka tanpa bersentuhan dapat tertular Covid-19. Selain itu berita yang beredar setahun silam yaitu di Iran, bahwa mengonsumsi alkohon methanol beracun diyakini dapat menyebuhkan Covid-19. Banyak beritaberita simpang siur lainnya yang tidak diketahui sumber maupun faktanya yang belum teruji. Untuk itu, World Health Organization (WHO) telah melakukan identifikasi terhadap beberapa pokok bahasan misinformasi terkait Covid-19. Pokok bahasan ini meliputi penyebab, gejala dan pola penularan, pengobatan dan pencegahan, maupun dampaknya terhadap kehidupan (Nasir et al., 2020).

Menurut studinya, misinformasi Covid-19 telah menyebar secara global. Hal ini menciptakan kecemasan dan ketidakpastian mengenai virus corona di dalam lingkup masyarakat (Mian \& Khan, 2020). Misinformasi mengenai Covid-19 memberikan sebuah rasa aman yang salah bagi masyarakat. Sebuah bukti studi menunjukkan sebuah ketidak benaran dapat berkembang dan sangat mudah untuk menyebar dibandingkan dengan sebuah kebenaran (Vosoughi et al., 2018). Hal ini juga sudah terjadi di Indonesia, misinformasi telah menyebar secara masif di berbagai platform media sosial karena jika dilihat masyarakat Indonesia sebagian besar adalah pengguna aktif media sosial.

Semakin melonjaknya berita palsu yang beredar mengenai Covid-19 di media sosial, pemerintah Indonesia telah mengambil langkah untuk mengantisipasi persebaran isu misinformasi ini melalui situs resmi pada kolom Hoax Buster covid19.go.id.. Pada kolom ini memberikan klarifikasi mengenai beritaberita yang beredar di media sosial mengenai Covid-19, namun belum dapat dibuktikan kebenarannya. Jadi dapat dikatakan bahwa kolom Hoax Buster memberikan penjelasan dan meluruskan apa yang sebenarnya terjadi berdasarkan berita mengenai Covid-19 yang beredar.

Hoax Buster merupakan salah satu langkah efektif yang diambil pemerintah Indonesia dalam menyampaikan informasi kepada masyarakat. Masyarakat dapat mengaksesnya melalui website resmi covid19.go.id pada kolom Hoax Buster kapanpun dan dimanapun. Karena dalam website ini selalu memberikan informasi yang up-to-date mengenai klarifikasi hoaks yang beredar mengenai Covid-19. Dalam kolom Hoax Buster, ditampilkan berita-berita yang tersebar dari berbagai platform media sosial seperti Facebook, Youtube, Instagram, Twitter, maupun berbagai portal berita yang ada di Indonesia. Selanjutnya, pada kolom Hoax Buster diberikan penjelasan mengenai berita-berita yang kebenarannya masih perlu diluruskan.

Berita-berita palsu yang beredar pun menjadi sebuah krisis kehidupan di Indonesia selama pandemic Covid-19 ini. Berita palsu ini mengancam kesehatan masyarakat Indonesia tidak lagi dapat disangkal. Misalnya berbagai pemberitaan mengenai bahaya vaksin Covid-19 menciptakan kembali kepanikan publik. Masyarakat dibuat was-was dengan pemberitaan efek samping daripada vaksin yang disinyalir 
dapat menyebabkan kematian. Banyak masyarakat yang akhirnya tidak mematuhi aturan pemerintahan untuk mendapatkan suntik vaksinasi Covid-19. Akibatnya ini menjadi salah satu penghalang untuk menekan angka Covid19 nasional.

\section{Kajian Literatur}

2.1 Arus Informasi saat Pandemi Covid-19

Perilaku pencarian dan pengumpulan informasi yang konstan dari lingkungan, memungkinkan adanya sebuah adaptasi daripada kelangsungan hidup manusia. Manusia secara tidak sadar selalu mencari informasi secara terus-menerus guna beradaptasi dan bertahan hidup (Spink \& Cole, 2004). Dapat ditarik kesimpulan bahwa perilaku terkait mengenai sebuah informasi adalah naluri alamiah manusia. Jika dihubungkan dengan situasi wabah Covid-19 yang menciptakan kepanikan masal dimana seluruh masyarakat diliputi perasaan ketidakpastian, kecemasan, dan perasaan kekhawatiran yang tinggi. Hal ini didukung oleh pernyataan bahwa terdapat korelasi antara emosi dan kognisi terhadap teknologi informasi. Manusia memiliki dorongan untuk beradaptasi dengan teknologi informasi. Ketika mendapatkan informasi, manusia akan memutuskan untuk menggunakan informasi atau tidak (Montesi dan lvarez Bornstein, 2017).

Pada awal krisis Covid-19, banyak pihak seperti para ahli kesehatan maupun WHO, serta pemerintah pihak tidak mampu memberikan pernyataan yang jelas mengenai pandemi ini. Sedangkan, dilain sisi masyarakat menunggu pernyataan yang mereka harapkan. Hal ini menciptakan ketidak pastian dan kebutuhan akan sebuah informasi yang besar. Kesenjangan informasi dari berbagai sumber-sumber yang tidak diketahui pun terjadi, sehingga banyak hoaks atau berita palsu yang menyebar. Urgensi situasi pandemi ini mendorong masyarakat untuk mencari solusi cepat, dengan mencari atau menerima informasi mengenai Covid-19. Sehingga masyarakat mengonsumsi informasi yang belum tentu akurat. Pada titik ini hoaks mengenai Covid-19 mengalir secara luas. Pada intinya, Covid19 bahwa orang secara aktif mengonsumsi informasi yang meningka dari $60 \%$ menjadi $92 \%$ selama pandemi. Selain itu, deteksi berita palsu meningkat sebesar $12 \%$ selama pandemi. Hal ini disebabkan oleh tingkat informasi yang berhubungan secara positif dengan kapasitas deteksi berita palsu (Al-Zaman, 2021).

\subsection{Hoaks dan Media Sosial}

Hoaks diartikan sebagai sebuah bentuk penipuan yang memiliki tujuan untuk membuat kelucuan atau bahaya dalam kamus Oxford (2017). Jika dalam Bahasa Indonesia, hoaks adalah berita palsu, dusta, atau kabar bohong. Sedangkan arti hoaks dalam kamus Bahasa Inggirs, yaitu cerita bohong atau memperdayakan (Juditha, 2018). Hoaks dapat terjadi karena misinformasi maupun disinformasi. Misinformasi merupakan sebuah informasi yang salah, tetapi orang yang menyebarkannya percaya bahwa informasi yang disebarkannya benar. Sedangkan disinformasi merupakan sebuah informasi yang jelas salah, namun sengaja disebarkan dengan maksud dan tujuan tertentu, sehingga dapat 
disimpulkan bahwa misinformasi dan disinformasi termasuk dalam gangguan informasi (Silalahi \& Sevilla, 2020).

Misinformasi paling banyak menyebar pada media sosial. Media sosial tidak hanya untuk berkomunikasi dengan mendekatkan yang jauh tanpa adanya jarak, namun juga sering menjadi sumber masalah sosial seperti penyebaran kebencian, hasutan, dan termasuk penyebaran hoaks (Juditha, 2018). Semua interaksi komunkasi pada media sosial adalah bagian dari transaksi dengan menggunakan lebih dari satu computer yang biasanya disebut dengan jaringan Computer Mediated Communication $(C M C)$, yaitu sebuah konsep teori yang menggambarkan sebuah bentuk komunikasi untuk bertukar dan memahami informasi, menyandikan kode, kemudian mengirimkan kembali pesan dengan jaringan telekomunikasi (Desember, 1996). Sehingga dapat disimpulkan bahwa CMC merupakan bentuk komunkasi yang dilakukan melalui mediasi teknologi digital.

\section{Metodelogi Penelitian}

Studi ini menggunakan metode kualitatif dengan menggunakan kualitatif non-interaktif. Kualitatitf non-interaktif merupakan sebuah penelitian analisis dokumen terhadap konsep-kosep yang dipakai. Dalam melakukan penelitian ini akan diidentifikasi, dipelajari, dan diberikan sebuah sinstesa data yang tersedia untuk diberikan pemahaman mengenai konsep yang diteliti. Pendekatan penelitian kualitatif yang dipilih adalah analytical concept atau analisis konsep. Analisis konseptual adalah sebuah metode kualitatif yang menjelaskan dan mendefinisikan sebuah konsep secara mandalam. Sebuah analisis konseptual berawal dari pernyataan sebuah ide mengenai konsep yang saling berkaitan dengan ide lainnya. Untuk menjelaskan dan mendefinisikan ide tersebut diperlukan observasi secara mendalam, serta membaca ide-ide terdahulu untuk menjadi sebuah acuan (Neuman, 2014).

Analisis konseptual dilakukan dengan menggunakan data-data sekunder seperti jurnal internasional, artikel jurnal internasional, maupun sumber-sumber kredibel lainnya. Teknik pengumpulan, pengolahan, serta analisis dari data sekunder termasuk serangkaian proses untuk mengembangkan dan memperjelas sebuah konsep abstrak dari ide terdahulu (Neuman, 2014).

\section{Hasil dan Diskusi Penelitian}

\subsection{Hasil Temuan Penelitian}

Dalam penelitian yang dilakukan oleh Narila Mutia Nasir, Baequni, dan Mochammad Iqbal Nurmansyah di tahun 2020 yang berjudul "Misinformation ReIated To Covid-19 in Indonesia", ikut andil dalam memberikan kontribusi terkait dalam penyebaran misinformasi mengenai Covid-19 di Indonesia. Penelitian yang dilakukan bersifat crosssectional dengan menyebarkan kuesioner secara online dengan bertujuan untuk melihat pengetahuan responden tentang informasi yang salah mengenai Covid-19 sangat meluas di media sosial. Seorang responden dikategorikan 'informed' ketika mereka memiliki pengetahuan 
yang benar mengenai berita atau informasi yang beredar. Sebaliknya, respnden dikategorikan sebagai 'missinformed' ketika mereka memiliki kepercayaan terhadap berita atau informasi yang salah. Sedangkan, responden yang dikategorikan 'uninformed' ketika mereka tidak memiliki pengetahuan mengenai fakta yang terjadi. Hal ini dapat disimpulkan bahwa terdapat sekelompok orang yang tetap salah informasi dan kurang informasi mengenai Covid-19. Srategi untuk melawan dan menghentikan penyebaran misinformasi dengan pendekatan kontraintuitif (Alemanno, 2018).

\section{Penelitian selanjutnya berjudul \\ "How Trust in lnformation Sources Influences Preventative Measures Compliance during the COVID-19 Pandemic" yang dilakukan oleh Sherry} A, dkk. Penelitian ini bertujuan untuk mengeksplorasi bagaimana kepercayaan pada sumber informasi formal (pemerintah maupun media) dan sumber informal (interpersonal) mengenai Covid19 mempengaruhi kepatuhan masyarakat terhadap tindak antisipasi dan pencegahan penularan Covid-19. Analisis data dalam penelitian ini menggunakan permodelan persamaan structural dengan menguji hubungan hipotesis rasa kepercayaan antara sumber informasi, perilaku pencegahan, dan pembatasan sosial. Penelitian ini menunjukkan bahwa pemahaman mengenai penyebab Covid-1 terkait dengan kepercayaan pada sumber informasi formal, yaitu pemerintah dan media, tidak pada informasi informal. Sedangkan pemahaman dan pencegahan Covid-19 terkait dengan kepercayaan pada sumber informal, tetapi tidak dengan kepercayaan pada sumber informasi formal. Kekhawatiran tertular COVID-19 terkait dengan kepercayaan pada sumber informasi formal, tetapi tidak pada sumber informasi informal. Penelitian ini memiliki implikasi yang penting penting bagi pedoman kebijakan kesehatan masyarakat yang berpusat pada pesan media yang jelas dan jujur (Maykrantz et al., 2021).

\section{Penelitian yang dilakukan M.J} Fernández-Torres, Martínez, dan Sánchez dari Universidad de Málaga Spanyol berjudul "Infodemic and Fake News in Spain during the COVID-19 Pandemic" saat tahun 2020. Penelitian ini bertujuan untuk melihat bagaimana penyebaran berita palsu mengenai COVID-19 dapat mempengaruhi masyarakat dan dampaknya terhada opini publik.Selain itu, penelitian ini memiliki tujuan sekunder, yaitu untuk mengetahui cara utama di mana masyarakat telah diberitahu tentang pandemi, untuk mengidentifikasi sumber-sumber yang memberikan kredibilitas lebih besar, mengetahui tentang penilaian informasi kelembagaan, serta untuk mengidentifikasi isi dari mayoritas hoaks yang diterima serta penyebaran yang masyarakat miliki. Penelitian oleh mereka bertiga menggunakan kuesioner sebagai data sekunder, memberikan kontribusi baru dalam kaitannya dengan infodemik di masa pandemi di Spanyol. Beberapa aspek yang terkait dengan pesan instan dan jejaring sosial sebagai saluran utama penyebaran berita bohong atau palsu, kurangnya kredibilitas opini publik terhadap media secara umum, serta konten utama yang disinformatif. Hasil 
daripada penelitian ini adalah pesan mengenai Covid-19 disalurkan secara utama oleh stasiun televisi dan pers online, kemudian diikuti oleh Whatsapp dan Facebook. Namun, selain situs web, media cetak dan radio dianggap sebagai media yang paling dapat diandalkan, karena merupakan saluran dengan penyebaran berita palsu terkait COVID19 paling rendah. Perlu dicatat bahwa rendahnya keandalan yang diberikan kepada WhatsApp dan jejaring sosial Facebook, karena dianggap lebih mungkin menghasilkan berita palsu, meskipun merupakan dua saluran utama akses informasi. Penetrasi besar-besaran baik Facebook dan WhatsApp menjelaskan bahwa masyarakat menerima berita melalui jaringan ini terkait dengan pandemi, namun berita yang dibagikan belum diketahui kredibilitasnya, benar atau palsu. Sehingga pada akhirnya masyarakat membutuhkan komunikasi yang efektif oleh para actor utama agar masyarakat dapat memahami dan mengerti situasi apa yang sebenarnya terjadi (Fernández-Torres et al., 2021).

Pandemi COVID-19 membuat media sosial lebih terekspos dalam penyebaran informasi. Hal ini tidak hanya merugikan pengguna media sosial, namun juga dalam pembangunan berkelanjutan secara nasional. Penelitian yang berjudul "The Negative Role of SociaI Media During the COVID-19 Outbreak" yang dilakukan oleh Harith Yas, dkk., membahas alasan penggunaan media sosial selama pandemi COVID-19 dengan menyaring berbagai topik, serta menilai dampak misinformasi di media sosial. Manfaat media sosial telah menyebabkan peningkatan terus-menerus dalam penggunaan media sosial selama periode pandemi. Hal ini disertai dengan tantangan seperti rumor, misinformasi, dan kesalahpahaman penyakit. Untuk itu penelitian ini bertujuan untuk membahas pravalensi misinformasi media sosial dan dampak psikologis pada pengguna selama COVID-19. Hasil penelitian menunjukkan bahwa Whatsapp, Twitter, dan Youtube adalah sebuah platform media sosial yang dipakai paIing banyak oleh responden. Banyak responden mengakui bahwa selama pandemi Covid19 mereka beralih ke media sisal sebagai sumber informasi mengenai Covid-19, yang bertujuan untuk mengetahui cara mencegah diri mereka dari Covid-19. Informasi dan berita yang menyesatkan masyarakat mengenai pandemi Covid-19 dapat mengancam keselamatan publik. Meskipun media sosial dapat menjadi alat pertukaran berbagai informasi kepada masyarakat, sifatnya yang liar tanpa jaminan membuat pengguna dapat terpapar informasi yang salah. Pada studi ini merekomendasikan pemerintah dan lembaga kesehatan untuk mengembangkan langkah-langkah untuk memperbaiki informasi yang salah dan rumor di media sosial secara bersamaan (Yas et al., 2021).

Selanjutnya, penelitian yang dilakukan oleh K. Chen, Yuni Luo, dkk. yang berjudul "Characteristics of Misinformation Spreading on Social Media During the COVID-19 Outbreak in China: A Descriptive Analysis" menggambarkan karakteristik misinformasi mengenai pandemi Covid19 pada media sosial di China, termasuk tipologi, misinformasi yang paling banyak disebutkan, dan timeline 
perkembangannya. Pada Penelitian ini dijelaskan bahwa tren misinformasi memiliki korelasi yang signifikan dengan situasi darurat. Sehingga, salah satu cara untuk menghilangkan sarang misinformasi adalah dengan menawarkan informasi yang tepat sasaran dan akurat terlebih dahulu berdasarkan prediksi situasi wabah COVID-19. "Efek kupukupu" dari komunikasi informasi yang abu-abu dapat mengakibatkan sejumlah konsekuensi, dan ini telah dibuktikan dengan respons awal China terhadap wabah COVID-19, sehingga diperlukan adanya komunikasi yang efektif. Komunikasi yang efektif adalah proses yang tepat waktu, dinamis, dan transparan, dan organisasi serta media harus memperbarui komunikasi saat informasi tambahan tersedia. Oleh karena itu, dalam proses yang terbuka dan transparan, semua pemangku kepentingan risiko memiliki kesempatan untuk mengakses informasi yang sebenarnya dan menyatakan posisinya. Dalam menyikapi serta melawan krisis misinformasi di media sosial, seluruh lapisan masyrakat seperti jurnalis, pendidik, cendikiawan, dan warga Negara harus bersama-sama dan bertanggung jawab untuk memperbaiki informasi yang salah (Chen et al., 2021).

\subsection{Diskusi Penelitian}

Berdasarkan hasil penelitian melalui studi literatur dengan penelitanpenelitian terdahulu, dapat dikatakan bahwa dengan adanya wabah pandemi Covid-19, mampu memotivasi setiap individu dalam masyarakat untuk mengakses berita atau informasi seputar Covid-19 pada media sosial. Hal ini terjadi karena adanya dorongan dan motivasi secara alamiah dari dalam diri dalam kondisi kepanikan masal. Mereka menyerap informasi terkait Covid-19 secara mentah-mentah, tidak melakukan filterisasi informasi. Alhasil, banyak misinformasi yang mereka dapatkan mengenai wabah Covid-19 ini. Misinformasi yang mereka dapatkan melalui sumber-sumber informal dapat mempengaruhi mereka dalam bertindak. Misinformasi mengenai vaksin mematikan menjadi salah satu contoh misinformasi yang menjadi penghambar dalam menekan angka Covid-19 secara nasional.

Arus informasi yang meningkat pada kondisi Covid-19 tidak dapat dihindari. Tidak ada satupun yang dapat menghentikan terpaan media sosial. Namun, untuk menekan berita bohong atau hoaks terkait Covid-19, masyarakat perlu diberikan pemahaman secara kognitif. Pentingnya langkah dalam meningkatkan literasi dari sumber yang formal dan kredibel sangat diperlukan. Ledakan informasi mengenai Covid-19 mengalami kesulitan dalam memilah dan memberi makna atas banyaknya pesanpesan yang ada.

Kolom Hoax Buster menjadi sebuah tantangan bagi pmerintah. Karena harus menarik perhatian masyarakat untuk membaca dan menggunakan kemampuan kognitifnya. Jika dibandingkan dengan hoaks, biasanya lebih mudah diterima di masyarakat karena gaya bahasa penyampainnya yang hiperbolis, memberikan gambar-gambar menarik, dan sedikit teks. Karena tujuan daripada hoaks yaitu untuk membuat orang gugup dan menyebarkan informasi tersebut kepada orang lain. 


\section{Kesimpulan}

Berdasarkan hasil penelitian kualitatif dengan analisis konseptual, peneliti menyimpulkan bahwa situs resmi pada kolom Hoax Buster covid19.go.id, merupakan salah satu bentuk langkah pemerintah Indonesia dalam mengantisipasi persebaran isu-isu hoaks terkait Covid-19. Penyampaian klarifikasi misinformasi yang beredar di media sosial adalah salah satu wujud pemerintah Indonesia dalam meningkatkan kemampuan literasi masyarakat Indonesia. Penggunaan media sosial yang paling banyak dijumpai dengan kontekkonten yang berisikan misinformasi yaitu media sosial Twitter.

Hoaks biasanya dapat diterima di benak masyarakat dengan sangat mudah karena biasanya hoaks menggunakan gaya bahasa yang hiperbolis, menyajikan gambar-gambar menarik, dan hanya sedikit teks. Tujuan daripada hoaks adalah untuk menciptakan rasa gugup dan panik, serta meyebarkannya keada orang lain. Covid-19 merupakan isu yang kuat untuk dijadikan hoaks karena kurangnya kesadaran dan sedikit wawasan mengenai Covid-19.

Dengan demikian, pemerintah Indonesia mengambil tindakan terhadap misinformasi yang beredar melalui kolom Hoax Buster ada situs resmi pemerintah. Dalam pengelolaannya, kolom Hoax Buster covid19.go.id selalu up-to-date dalam menaggapi misinformasi yang beredar pada berbagai media sosial Instagram. Hal ini bertujuan agar masyarakat tidak menerima dan menyerap informasi secara mentahmentah karena pemerintah merupakan sumber informasi formal, dimana informasi yang disampaikan dan dibagikan sudah tentu kredibel. Kolom Hoax Buster juga menjadi salah satu tools pemerintah dalam menekan angka Covid19 secara nasional.

\section{Daftar Pustaka}

Al-Zaman, M. S. (2021). COVID-19Related Social Media Fake News in India. Journalism and Media, 2(1), 100-114.

https://doi.org/10.3390/journalmedia 2010007

Alemanno, A. (2018). How to Counter Fake News? A Taxonomy of Antifake News Approaches. European Journal of Risk Regulation, 9(1), 15. https://doi.org/10.1017/err.2018.12

Chen, K., Luo, Y., Hu, A., Zhao, J., \& Zhang, L. (2021). Characteristics of Misinformation Spreading on Social Media During the COVID-19 Outbreak in China: A Descriptive Analysis. Risk Management and Healthcare Policy, Volume 14, 1869-1879. https://doi.org/10.2147/rmhp.s31232 7

Fernández-Torres, M. J., AlmansaMartínez, A., \& Chamizo-Sánchez, R. (2021). Infodemic and fake news in spain during the COVID-19 pandemic. International Journal of Environmental Research and Public Health, 18(4), 1-13. https://doi.org/10.3390/ijerph180417 81

Juditha, C. (2018). Interaksi Komunikasi 
Hoax di Media Sosial Serta Antisipasinya. Journal Pekommas, 3(1), 31-34.

Maykrantz, S. A., Gong, T., Petrolino, A. V, Nobiling, B. D., \& Houghton, J. D. (2021). How Trust in Information Sources Influences Preventative Measures Compliance during the COVID-19 Pandemic.

Mian, A., \& Khan, S. (2020). Coronavirus: The spread of misinformation. BMC Medicine, $18(1)$, $18-19$. https://doi.org/10.1186/s12916-02001556-3

Nasir, N. M., Baequni, B., \& Nurmansyah, M. I. (2020). Misinformation Related To Covid19 in Indonesia. Jurnal Administrasi Kesehatan Indonesia, 8(2), 51. https://doi.org/10.20473/jaki.v8i2.20 20.51-59

Neuman, W. L. (2014). Social Research Methods: Qualitative and Quantitative Approaches. PEARSON.

Silalahi, R. R., \& Sevilla, V. (2020). Rekontruksi Makna Hoaks di Tengah Arus Informasi Digital. Global Komunika, 1(1), 8-17.

Spink, A., \& Cole, C. (2004). A human information behavior approach to a philosophy of information. Library Trends, 52(3).

Vosoughi, S., Deb, R., \& Aral, S. (2018). False news is big news. MIT Initiative on the Digital Economy
Research Brief, 359(6380), 11461151.

http://ide.mit.edu/sites/default/files/p ublications/2017 IDE Research Brief False News.pdf

Yas, H., Jusoh, A., Streimikiene, D., Mardani, A., Nor, K. M., Alatawi, A., \& Umarlebbe, J. H. (2021). The Negative Role of Social Media During the COVID-19 Outbreak. International Journal of Sustainable Development and Planning, 16(2), 219-228. https://doi.org/10.18280/ijsdp.16020 2 